iti

Universität Hamburg
Faculty Economics and Social Sciences

Chair for Economic Policy

VIKTORIA C. E. LANGER / WOLFGANG MAENNIG / FELIX J. RICHTER NEWS SHOCKS IN THE DATA: OLYMPIC GAMES AND THEIRCMACSROECONOMIC EFFECTS - REPLY government News bidders literature structural because propensity change Journal

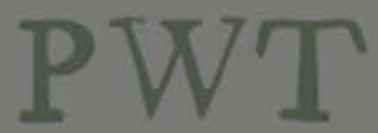

openness

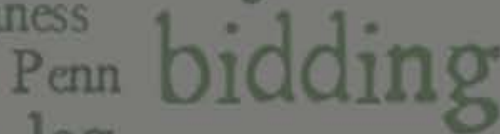
Portier $\log$ use year
variable

include

argue nomic set wer Unites apita States Most Table

\section{HAMBURG CONTEMPORARY}

shocks

results Economics including match other
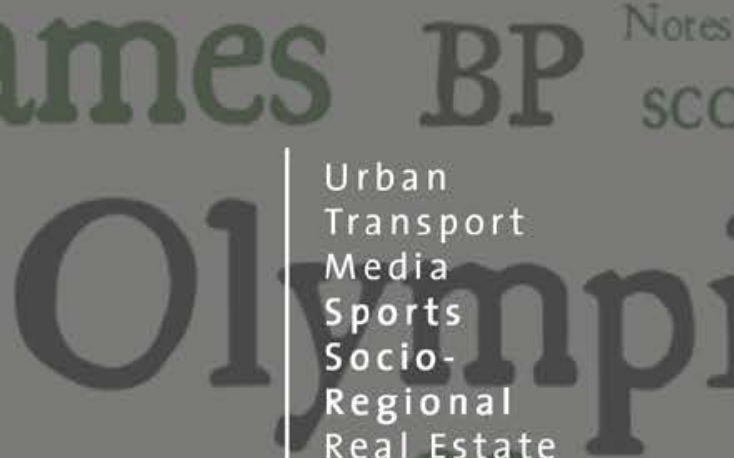

Urban

Transport

Media

Sports

Socio-

Regional

Real Estate

Architectural

hosts per

ECONOMIC DISCUSSIONS lagged

before Barro

mega data

investment fertility

terms Column

measure analyses

differences

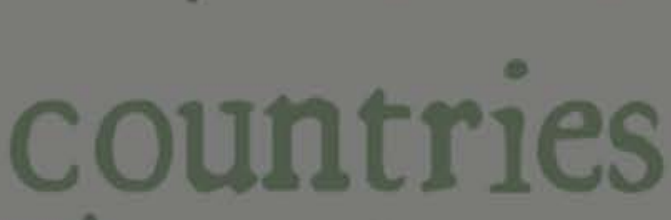

Richter sample

Uganda possible matching determinants all No.52 using model between rate problem 


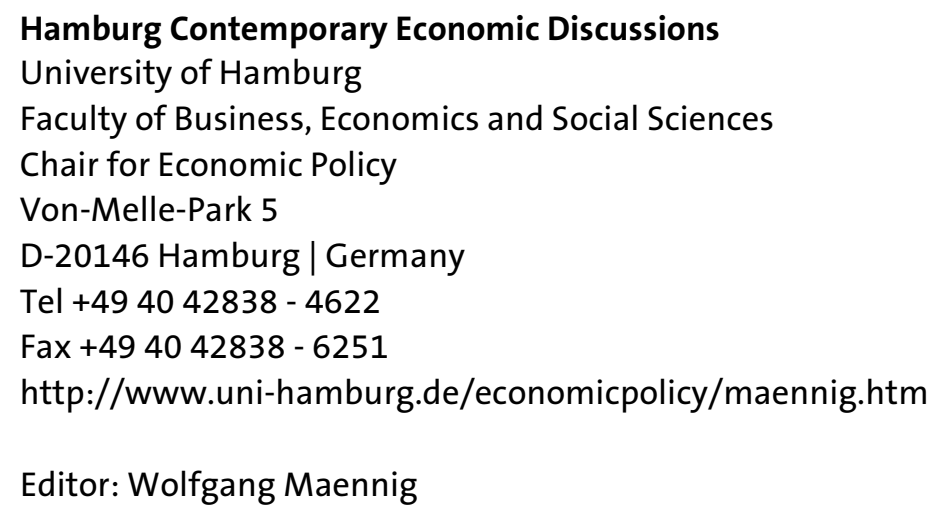




\title{
News shocks in the data: Olympic Games and their macroeconomic effects - Reply*
}

\begin{abstract}
Recent analyses relate increases in the growth rate of countries to anticipation effects caused by bidding for the Olympic Games, so called news shocks. We argue that these findings should be interpreted cautiously. First, these analyses may suffer from an omitted variable bias because they neglect key determinants of economic growth. Second, these analyses compare the bidders for the Olympic Games to all other countries in the world, which constitutes a comparison between groups that show large differences in their structural characteristics. We show that including established determinants of economic growth and comparing the bidders to a suitable control group may lead to a complete disappearance of the anticipated economic effects of Olympic Games.
\end{abstract}

Keywords: Anticipated shock, Olympic Games, GDP growth, matching, mega event

JEL classification: E62, E65, F1, L83

Version: June 2015

\section{Introduction}

Recently, Brückner and Pappa [BP] (2015) borrowed from the news shock literature (Beaudry \& Portier, 2004, 2006; Davis, 2007; Schmitt-Grohé \& Uribe, 2012) to analyze the economic effects of bidding for (or hosting) the Olympic Games on several macroeconomic indicators. They argue that both the decision to apply for the Games, as well as the selection as a host city, constitute a news shock, which increases investment, consumption, and output significantly nine to seven years before the actual event in bidding countries. For Olympic hosts, they also find positive effects three to five years preceding the games. Furthermore, the coefficients estimated by BP would indicate that the anticipation of bidding for the Olympic Games eight years before the celebration of the games significantly increases per capita GDP growth by 0.99 percentage points.

\footnotetext{
* We thank Markus Brückner for generously providing data and code to replicate Brückner and Pappa (2015).
} 
BP's results contrast with most literature on the economics of mega sport events. This literature primarily finds no evidence for measurable economic impacts of the Olympic Games. These results hold across geographical units (e.g., cities, counties, Metropolitan Statistical Areas, and states), model specifications, estimation methods, and dependent variables (e.g., employment, wages, and taxable sales) (Coates \& Humphreys, 2008). One of the few "positive" studies, Rose and Spiegel (2011), suffers from an inappropriate treatment methodology (Maennig \& Richter, 2012).

We argue that the BP results should be interpreted cautiously. First, the BP analysis does not consider well-established determinants of economic growth, leading to a potential omitted variable bias. Second, the BP analyses compare the economic performance of countries such as Australia, Canada, France, Germany, Japan, United Kingdom, and the United States that bid for Olympic Games to all other countries in the world, including much less-privileged countries such as Uganda, Burundi, and Tanzania. Therefore, the results may suffer from selection bias.

To address the first problem, we refer to the literature on economic growth, which identified investment growth, government spending growth, fertility, life expectancy, and human capital, among others, as key determinants (Barro, 1991, 2003). We tackle the second problem by employing a matching procedure. We use propensity score matching to identify countries that are structurally similar to the bidding and hosting countries, but are not bidders themselves.

We find that including the determinants of economic growth or matching bidders/hosts to a suitable control group reduces the economic effects of Olympic Games. Combining both approaches eliminates all significant effects. We also find that these results are robust to the inclusion of a substantially revised data set.

\section{Empirical strategy and results}

Parallel to BP, we rely on data from the Penn World Table (PWT), version 7.0 as described in Heston et al. (2011), for the period 1950-2009. We extend these data by including standard determinants of economic growth from the World Bank (2011) including the fertility rate, life expectancy at birth, the stock of human capital (share of tertiary 
schooling), the degree of international openness, a measure of political stability, as well as the change in the terms of trade.

The baseline empirical strategy is in accordance with BP. To maintain a short presentation, we restrict ourselves to the effects on GDP per capita growth. Olympic bidders and hosts are denoted as 1 in the respective year and enter the equations with 10 lags and leads to capture possible effects. We also include the lagged values of the GDP growth rate and of government spending, as well as country level fixed effects and a full set of year fixed effects. Table 1 summarizes our main results. Column (1) contains the replicated results from $B P$.

To overcome the problem that the BP regression compares bidders and hosts for the Olympic Games to all other countries, we use the propensity score procedure of Rosenbaum and Rubin (1983). The covariates used for the estimation of the propensity score are required to affect the outcome variable (i.e., GDP growth) and the probability to become a bidder for the Olympic Games; they should preferably be measured before the treatment or not vary over time (Caliendo \& Kopeinig, 2008). Because we attempt to base the matching on the earliest possible year with as many available countries as possible, we face a tradeoff between lower data availability in the 1950s and the possibility that later outcomes may previously be influenced by participation in the Olympic Games. We select the year 1970, and include as covariates the five year lagged values of GDP, government spending, investment, consumption, and the population. We match the bidding countries using nearest neighbor matching and obtain a sample in which the structural differences between the bidders and the remaining countries are substantially reduced. ${ }^{1}$ Column (2) reports the results for the restricted sample of countries, which were matched to the Olympic bidders. The Olympic effects are slightly

\footnotetext{
${ }^{1}$ The bidding countries include Argentina, Australia, Austria, Belgium, Bulgaria, Bosnia and Herzegovina, Canada, Switzerland, China, Cuba, Egypt, Spain, Finland, France, UK, Germany, Greece, Hungary, Italy, Japan, South Korea, Mexico, Malaysia, Netherlands, Norway, Poland, Russia, Slovak Republic, Sweden, Thailand, Turkey, the US, and South Africa. The matched countries include Bolivia, Brazil, Barbados, Costa Rica, Denmark, Ecuador, Guatemala, India, Ireland, Iceland, Israel, Jamaica, Jordan, Kenya, Luxembourg, Namibia, Nigeria, New Zealand, Puerto Rico, Portugal, El Salvador, Seychelles, Syria, Uruguay, and Venezuela.
} 
lower. Most notably, the variance explained by the model is doubled compared with the $\mathrm{R} 2$ of $\mathrm{BP}$ of 0.12 .

Next, in accordance with a standard literature reference on economic growth (Barro, 1991, 2003), we include the lagged growth of investment, the price level, the share of tertiary schooling, 1/life expectancy at birth, the fertility rate, the ratio of government consumption to GDP, the openness ratio, the change in the terms of trade, and the polity2 score as a measure for the institutional quality. Column (3) reports the results for the full (non-matched) sample for the years 1960-2009. ${ }^{2}$ This specification reduces the Olympic hosting effects as well as the bidding effects.

Column (4), reports the results of a regression that both a) controls for the usual determinants of economic growth and $b$ ) restricts the sample to countries that match Olympic bidders/ hosts. The combination of these two simple perturbations reduces all anticipated effects beyond significance. The variance explained by our model is tripled compared with BP.

Finally, we use the recently substantially revised PWT 8.1 data set as a further robustness check. ${ }^{3}$ The PWT revision implies certain fundamental changes to selected data series. Figure 1 in the appendix illustrates some of these changes. Again, using our Barroaugmented model with matching countries, no significant Olympic effects can be identified (Column 5). Although the goodness of fit fails to meet model (4), the results are appealing because the coefficients of the structural variables are close to Barro (2003).

\footnotetext{
${ }^{2}$ Because the World Bank data are only available since 1960 and for a slightly different subset of countries, this leads to a reduction in sample size.

${ }^{3}$ Feenstra et al. (2015) describe the new version of the Penn World Table for the period 1950-2011 and explain some of the differences between the data sets.
} 
Tab. 1 Anticipation effects of hosting and bidding for the Olympic Games

\begin{tabular}{|c|c|c|c|c|c|}
\hline & $\begin{array}{c}(1) \\
\triangle \log (G D P)\end{array}$ & $\begin{array}{c}(2) \\
\triangle \log (G D P)\end{array}$ & $\begin{array}{c}(3) \\
\triangle \log (G D P)\end{array}$ & $\begin{array}{c}(4) \\
\triangle \log (G D P)\end{array}$ & $\begin{array}{c}(5) \\
\triangle \log (G D P)\end{array}$ \\
\hline \multirow[t]{2}{*}{ L. $\Delta \log (G D P)$} & 0.0147 & $0.0890^{\circ}$ & 0.0166 & 0.115 & 0.184 \\
\hline & $(0.0301)$ & $(0.0499)$ & $(0.0489)$ & $(0.0779)$ & $(0.0723)$ \\
\hline \multirow[t]{2}{*}{ L. $\Delta \log$ (gov) } & 0.00494 & $0.0510^{\circ}$ & -0.0215 & 0.0158 & -0.00218 \\
\hline & $(0.0105)$ & $(0.0280)$ & $(0.0166)$ & $(0.0409)$ & $(0.0326)$ \\
\hline \multirow[t]{2}{*}{ L. $\Delta \log$ (investment) } & & & 0.00642 & -0.0107 & 0.0152 \\
\hline & & & $(0.00975)$ & $(0.0206)$ & $(0.0203)$ \\
\hline \multirow[t]{2}{*}{ L. $\Delta \log ($ срі) } & & & 0.0172 & $0.0343^{\prime \prime}$ & 0.00407 \\
\hline & & & $(0.0127)$ & $(0.0157)$ & $(0.0255)$ \\
\hline \multirow[t]{2}{*}{ Schooling } & & & $-0.0405^{\circ}$ & -0.0260 & 0.000437 \\
\hline & & & $(0.0201)$ & $(0.0186)$ & $(0.0240)$ \\
\hline \multirow[t]{2}{*}{ 1/Life expectancy } & & & 0.00243 & 2.035 & -3.490 \\
\hline & & & $(1.941)$ & (3.405) & (5.181) \\
\hline \multirow[t]{2}{*}{ Fertility rate } & & & -0.660 & -0.953 & -0.234 \\
\hline & & & $(1.148)$ & (1.035) & $(1.577)$ \\
\hline \multirow[t]{2}{*}{ Openness ratio } & & & -0.0239 & -0.114 & -0.0489 \\
\hline & & & $(0.0456)$ & $(0.0479)$ & $(0.0495)$ \\
\hline \multirow[t]{2}{*}{ Democracy } & & & 3.257 & $-3.429^{\circ}$ & 18.64 \\
\hline & & & $(2.172)$ & (1.798) & (3.264) \\
\hline \multirow[t]{2}{*}{ Change in terms of trade } & & & 0.0166 & -0.439 & 0.184 \\
\hline & & & $(0.0489)$ & $(0.702)$ & $(0.0723)$ \\
\hline \multirow[t]{2}{*}{ Bidding Country } & 0.291 & -0.144 & 0.708 & -0.241 & -0.305 \\
\hline & $(0.553)$ & $(0.691)$ & $(0.660)$ & $(0.786)$ & $(0.963)$ \\
\hline F.Bidding Country & -0.302 & -0.0633 & -0.685 & -0.703 & -0.901 \\
\hline & $(0.473)$ & $(0.473)$ & $(0.761)$ & $(0.860)$ & $(0.856)$ \\
\hline F2.Bidding Country & -0.522 & -0.638 & -0.911 & 0.614 & -1.643 \\
\hline & $(0.751)$ & (0.918) & $(0.753)$ & $(0.611)$ & (1.125) \\
\hline F3.Bidding Country & 0.776 & 0.797 & 0.274 & 0.0959 & -0.162 \\
\hline & $(0.355)$ & $(0.351)$ & $(0.532)$ & $(0.504)$ & $(0.704)$ \\
\hline F4.Bidding Country & 0.238 & 0.215 & 0.421 & -0.748 & 0.401 \\
\hline & $(0.309)$ & $(0.342)$ & $(0.531)$ & $(0.612)$ & $(0.675)$ \\
\hline F5.Bidding Country & -0.676 & -0.751 & -0.0747 & 0.165 & -1.016 \\
\hline & $(0.436)$ & (0.484) & $(0.635)$ & $(0.932)$ & (1.005) \\
\hline F6.Bidding Country & 0.603 & 0.229 & 0.623 & 0.233 & -0.283 \\
\hline & $(0.589)$ & (0.669) & (0.958) & $(0.513)$ & (0.984) \\
\hline F7.Bidding Country & 0.530 & $0.659^{\prime \prime}$ & 0.267 & 0.493 & 0.0871 \\
\hline & $(0.345)$ & $(0.307)$ & $(0.536)$ & $(0.417)$ & $(0.468)$ \\
\hline F8.Bidding Country & $0.981^{\prime \cdots}$ & $0.829^{\prime \prime}$ & $1.439 \%$ & 0.620 & 0.690 \\
\hline & $(0.327)$ & $(0.359)$ & $(0.503)$ & $(0.572)$ & $(0.435)$ \\
\hline F9.Bidding Country & 0.417 & $0.606^{\circ}$ & 0.887 & -0.509 & 0.289 \\
\hline & $(0.432)$ & $(0.363)$ & $(0.627)$ & $(0.787)$ & $(0.677)$ \\
\hline F10.Bidding Country & -0.0720 & -0.204 & -0.217 & 1.121 & -0.505 \\
\hline & $(0.745)$ & $(0.697)$ & $(0.876)$ & $(0.738)$ & $(0.649)$ \\
\hline F.Hosting Country & 0.904 & 0.768 & 1.518 & 1.704 & 0.000523 \\
\hline & $(0.654)$ & $(0.575)$ & $(0.982)$ & $(1.167)$ & $(0.829)$ \\
\hline F2. Hosting Country & $1.839^{\prime \prime}$ & $1.602^{\prime \prime}$ & $2.391^{\prime}$ & 0.831 & 1.502 \\
\hline & $(0.838)$ & $(0.755)$ & (1.291) & $(0.638)$ & (1.065) \\
\hline F3.Hosting Country & $1.731^{\prime \prime}$ & 1.617 & $1.241^{\prime}$ & 0.747 & -0.123 \\
\hline & $(0.360)$ & $(0.333)$ & $(0.694)$ & $(0.759)$ & $(0.937)$ \\
\hline F4. Hosting Country & 2.620 & 2.412 & $1.461^{\prime \prime}$ & 0.799 & 0.731 \\
\hline & $(0.571)$ & $(0.610)$ & $(0.737)$ & $(0.613)$ & $(0.712)$ \\
\hline F5.Hosting Country & $1.443^{\prime \prime}$ & $1.269^{\prime \prime}$ & 1.118 & 0.397 & 0.275 \\
\hline & $(0.628)$ & $(0.538)$ & (1.132) & $(1.284)$ & $(0.671)$ \\
\hline F6. Hosting Country & 0.650 & 0.282 & 1.037 & 0.470 & 0.125 \\
\hline & $(0.933)$ & $(0.896)$ & (1.329) & $(0.626)$ & $(1.255)$ \\
\hline F7. Hosting Country & -0.0441 & 0.0653 & 0.201 & -1.703 & 0.134 \\
\hline & $(0.477)$ & $(0.437)$ & $(0.522)$ & $(1.908)$ & $(0.757)$ \\
\hline F8. Hosting Country & -0.379 & -0.386 & -1.336 & 0.129 & -1.832 \\
\hline & $(0.988)$ & $(0.945)$ & (1.754) & $(0.508)$ & $(2.002)$ \\
\hline F9. Hosting Country & 0.329 & 0.296 & 0.381 & 0.211 & -0.740 \\
\hline & $(0.344)$ & $(0.290)$ & $(0.526)$ & $(0.726)$ & (0.961) \\
\hline F10.Hosting Country & 0.612 & 0.625 & 0.296 & 0.115 & -0.609 \\
\hline & $(0.806)$ & $(0.805)$ & $(0.811)$ & $(0.0779)$ & $(1.008)$ \\
\hline Observations & 5866 & 2517 & 2414 & 1106 & 1169 \\
\hline$R^{2}$ & 0.118 & 0.225 & 0.172 & 0.353 & 0.217 \\
\hline$A I C$ & 41245.5 & 15711.7 & 16140.4 & 6288.2 & 6925.9 \\
\hline Barro & & & YES & YES & YES \\
\hline Matching & & YES & & YES & YES \\
\hline OECD & & & & & \\
\hline PWT 7.0 & YES & YES & YES & YES & \\
\hline PWT 8.1 & & & & & YES \\
\hline
\end{tabular}

Notes: Standard errors in parentheses are clustered on the country level in all models. ${ }^{*} p<0.1,{ }^{* *} p<$ $0.05,{ }^{* * *} p<0.01$. 


\section{Literature}

BARRO, R. J. (1991), Economic Growth in a Cross Section of Countries. The Quarterly Journal of Economics 106, 407-443.

BARRO, R. J. (2003), Determinants of economic growth in a panel of countries. Annals of economics and finance 4, 231-274.

BEAUDRY, P. / PORTIER, F. (2004), An exploration into Pigou's theory of cycles. Journal of Monetary Economics 51, 1183-1216.

BEAUDRY, P. / PORTIER, F. (2006), Stock Prices, News, and Economic Fluctuations. American Economic Review 96, 1293-1307.

BRÜCKNER, M. / PAPPA, E. (2015), News Shocks in the Data: Olympic Games and Their Macroeconomic Effects. Journal of Money, Credit and Banking 47, 1339-1367.

CALIENDO, M. / KOPEINIG, S. (2008), Some practical Guidance for the Implementation of Propensity Score Matching. Journal of Economic Surveys 22, 31-72.

COATES, D. / HUMPHREYS, B. R. (2008), Do economists reach a conclusion on subsidies for sports franchises, stadiums, and mega-events? Econ Journal Watch 5, 294-315.

DAVIS, J. M. (2007), News and the Term Structure in General Equilibrium, unpublished Manuscript, Northwestern University.

FEENSTRA, R. C. / INKLAAR, R. / TIMMER, M. P. (2015), The Next Generation of the Penn World Table. American Economic Review 105, 3150-3182.

HeStON, A. / SUMMERS, R. /ATEN, B. (2011), Penn World Table. Center for International Comparisons of Production, Income and Prices at the University of Pennsylvania.

MAENNIG, W. / RICHTER, F. J. (2012). Exports and Olympic Games: Is There a Signal Effect? Journal of Sports Economics 13, 635-641.

ROSE, A. K. / SPIEGEL, M. M. (2011), The Olympic Effect. The Economic Journal 121, 652-677.

ROSENBAUM, P. R. / RUBIN, D. B. (1983), The Central Role of the Propensity Score in Observational Studies for Causal Effects. Biometrika 70, 41-55.

SCHMITT-GROHÉ, S. / URIBE, M. (2012), What's news in business cycles. Econometrica 80, 27332764.

THE WORLD BANK (2011), World development indicators: UK Data Service. 


\section{Appendix}

Fig. 1 Comparison of data: PWT 7.0 versus PWT 8.1

United States
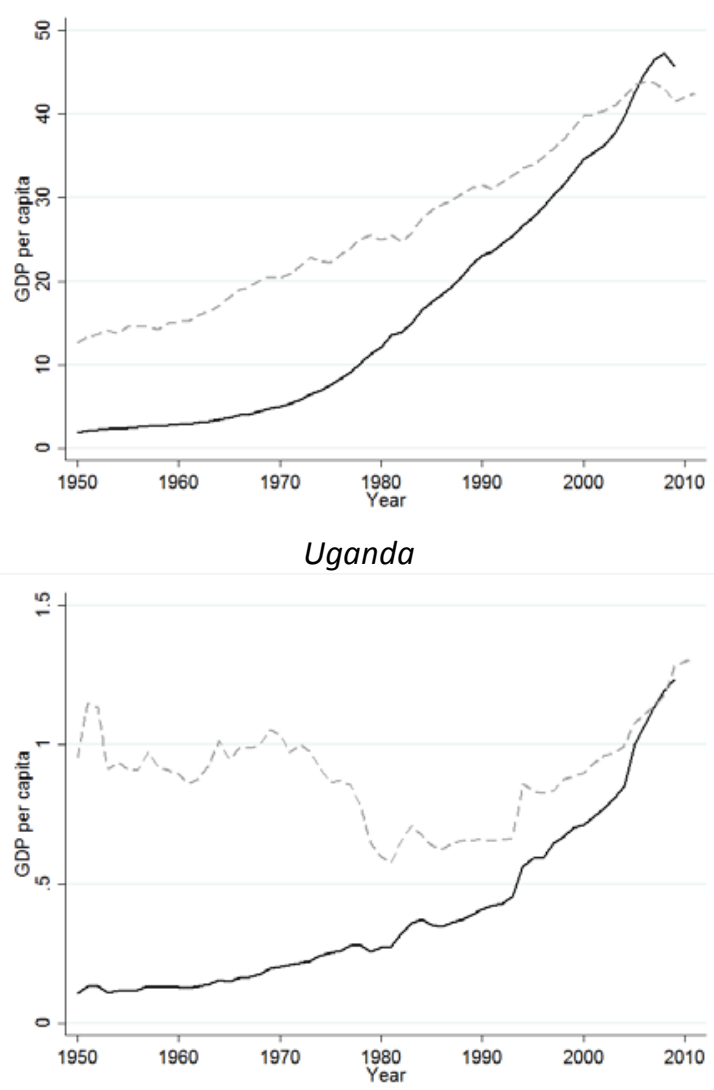

Switzerland
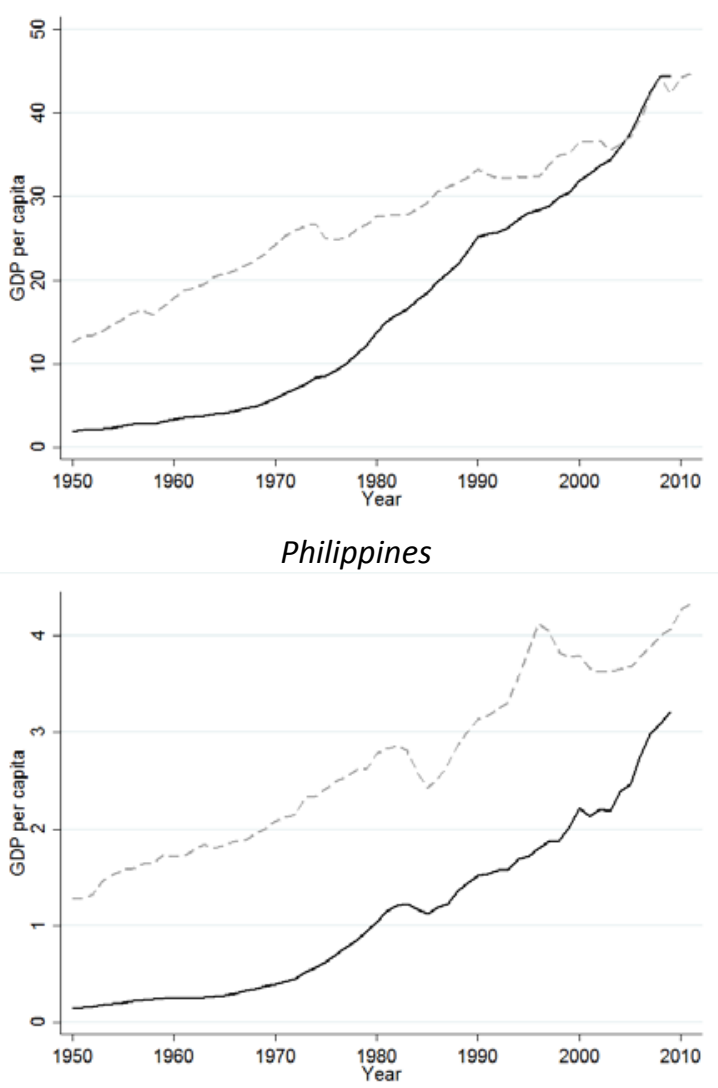

Notes: Illustration of differences between PWT 7.0 and PWT 8.1 for data on GDP per capita (in millions US\$) using the examples of the United States, Switzerland, Uganda, and the Philippines. Solid lines denote baseline data PWT 7.0, dashed lines denote revised data PWT 8.1. 


\section{Hamburg Contemporary Economic Discussions}

(Download: http://www.uni-hamburg.de/economicpolicy/hced.html)

52

51

50

49

48

47

46

45

44

42

41

40

39

38

LANGER, V. C. E. / MAENNIG, W. / RICHTER, F. J.: News Shocks in the Data: Olympic Games and their Macroeconomic Effects - Reply, 2015.

MAENNIG, W.: Ensuring Good Governance and Preventing Corruption in the Planning of Major Sporting Events - Open Issues, 2015.

MAENNIG, W. / VIERHAUS, C.: Who Wins Olympic Bids? 2015 ( $2^{\text {nd }}$ version).

AHLFELDT, G. M. / MAENNIG, W. / RICHTER, F.: Urban Renewal after the Berlin Wall, 2013.

BRANDT, S. / MAENNIG, W. / RICHTER, F.: Do Places of Worship Affect Housing Prices? Evidence from Germany, 2013.

ARAGÃO, T. / MAENNIG, W.: Mega Sporting Events, Real Estate, and Urban Social Economics - The Case of Brazil 2014/2016, 2013.

MAENNIG, W. / STEENBECK, M. / WILHELM, M.: Rhythms and Cycles in Happiness, 2013.

RICHTER, F. / STEENBECK, M. / WILHELM, M.: The Fukushima Accident and Policy Implications: Notes on Public Perception in Germany, 2014 (2 $2^{\text {nd }}$ version).

MAENNIG, W.: London 2012 - das Ende des Mythos vom erfolgreichen Sportsoldaten, 2012.

MAENNIG, W. / WELLBROCK, C.: London 2012 - Medal Projection Medaillenvorausberechnung, 2012.

MAENNIG, W. / RICHTER, F.: Exports and Olympic Games: Is there a Signal Effect? 2012.

MAENNIG, W. / WILHELM, M.: Becoming (Un)employed and Life Satisfaction: Asymmetric Effects and Potential Omitted Variable Bias in Empirical Happiness Studies, 2011.

MAENNIG, W.: Monument Protection and Zoning in Germany: Regulations and Public Support from an International Perspective, 2011.

BRANDT, S. / MAENNIG, W.: Perceived Externalities of Cell Phone Base Stations - The Case of Property Prices in Hamburg, Germany, 2011.

MAENNIG, W. / STOBERNACK, M.: Do Men Slow Down Faster than Women? 2010. 


\section{Hamburg Contemporary Economic Discussions}

(Download: http://www.uni-hamburg.de/economicpolicy/hced.html)

37

DU PLESSIS, S. A. / MAENNIG, W.: The 2010 World Cup High-frequency Data Economics: Effects on International Awareness and (Self-defeating) Tourism, 2010.

BISCHOFF, O.: Explaining Regional Variation in Equilibrium Real Estate Prices and Income, 2010.

FEDDERSEN, A. / MAENNIG, W.: Mega-Events and Sectoral Employment: The Case of the 1996 Olympic Games, 2010.

FISCHER, J.A.V. / SOUSA-POZA, A.: The Impact of Institutions on Firms Rejuvenation Policies: Early Retirement with Severance Pay versus Simple Lay-Off. A Cross-European Analysis, 2010.

FEDDERSEN, A. /MAENNIG, W.: Sectoral Labor Market Effects of the 2006 FIFA World Cup, 2010.

AHLFELDT, G.: Blessing or Curse? Appreciation, Amenities, and Resistance around the Berlin "Mediaspree", 2010.

FALCH, T. / FISCHER, J.A.V.: Public Sector Decentralization and School Performance: International Evidence, 2010.

AHLFELDT, G. / MAENNIG, W. /ÖLSCHLÄGER, M.: Lifestyles and Preferences for (Public) Goods: Professional Football in Munich, 2009.

FEDDERSEN, A. / JACOBSEN, S. / MAENNIG, W.: Sports Heroes and Mass Sports Participation - The (Double) Paradox of the "German Tennis Boom", 2009.

AHLFELDT, G. / MAENNIG, W. / OSTERHEIDER, T.: Regional and Sectoral Effects of a Common Monetary Policy: Evidence from Euro Referenda in Denmark and Sweden, 2009.

BJØRNSKOV, C. /DREHER, A. /FISCHER, J.A.V. /SCHNELLENBACH, J.: On the Relation Between Income Inequality and Happiness: Do Fairness Perceptions Matter? 2009.

AHLFELDT, G. / MAENNIG, W.: Impact of Non-Smoking Ordinances on Hospitality Revenues: The Case of Germany, 2009.

FEDDERSEN, A. / MAENNIG, W.: Wage and Employment Effects of the Olympic Games in Atlanta 1996 Reconsidered, 2009. 


\section{Hamburg Contemporary Economic Discussions}

(Download: http://www.uni-hamburg.de/economicpolicy/hced.html)

24

AHLFELDT, G. / FRANKE, B. / MAENNIG, W.: Terrorism and the Regional and Religious Risk Perception of Foreigners: The Case of German Tourists, 2009.

AHLFELDT, G. / WENDLAND, N.: Fifty Years of Urban Accessibility: The Impact of Urban Railway Network on the Land Gradient in Industrializing Berlin, 2008.

AHLFELDT, G. / FEDDERSEN, A.: Determinants of Spatial Weights in Spatial Wage Equations: A Sensitivity Analysis, 2008.

MAENNIG, W. /ALLMERS, S.: South Africa 2010: Economic Scope and Limits, 2008.

MAENNIG, W. / WELLBROCK, C.-M.: Sozio-ökonomische Schätzungen Olympischer Medaillengewinne: Analyse-, Prognose- und Benchmarkmöglichkeiten, 2008.

AHLFELDT, G.: The Train has Left the Station: Real Estate Price Effects of Mainline Realignment in Berlin, 2008.

MAENNIG, W. / PORSCHE, M.: The Feel-good Effect at Mega Sport Events - Recommendations for Public and Private Administration Informed by the Experience of the FIFA World Cup 2006, 2008.

AHLFELDT, G. / MAENNIG, W.: Monumental Protection: Internal and External Price Effects, 2008.

FEDDERSEN, A. / GRÖTZINGER, A. / MAENNIG, W.: New Stadia and Regional Economic Development - Evidence from FIFA World Cup 2006 Stadia, 2008.

AHLFELDT, G. / FEDDERSEN, A.: Geography of a Sports Metropolis, 2007.

FEDDERSEN, A. / MAENNIG, W.: Arenas vs. Multifunctional Stadia - Which Do Spectators Prefer? 2007.

AHLFELDT, G.: A New Central Station for a Unified City: Predicting Impact on Property Prices for Urban Railway Network Extension, 2007.

AHLFELDT, G.: If Alonso was Right: Accessibility as Determinant for Attractiveness of Urban Location, 2007.

AHLFELDT, G., MAENNIG, W.: Assessing External Effects of City Airports: Land Values in Berlin, 2007. 


\section{Hamburg Contemporary Economic Discussions}

(Download: http://www.uni-hamburg.de/economicpolicy/hced.html)

10

09

08

07

06

05

04

03

02

01

$04 / 2006$

$03 / 2006$

$02 / 2006$
MAENNIG, W.: One Year Later: A Re-Appraisal of the Economics of the 2006 Soccer World Cup, 2007.

HAGN, F. / MAENNIG, W.: Employment Effects of the World Cup 1974 in Germany.

HAGN, F. / MAENNIG W.: Labour Market Effects of the 2006 Soccer World Cup in Germany, 2007.

JASMAND, S. / MAENNIG, W.: Regional Income and Employment Effects of the 1972 Munich Olympic Summer Games, 2007.

DUST, L. / MAENNIG, W.: Shrinking and Growing Metropolitan Areas Asymmetric Real Estate Price Reactions? The Case of German Singlefamily Houses, 2007.

HEYNE, M. / MAENNIG, W. / SUESSMUTH, B.: Mega-sporting Events as Experience Goods, 2007.

DU PLESSIS, S. / MAENNIG, W.: World Cup 2010: South African Economic Perspectives and Policy Challenges Informed by the Experience of Germany 2006, 2007.

AHLFELDT, G. / MAENNIG, W.: The Impact of Sports Arenas on Land Values: Evidence from Berlin, 2007.

FEDDERSEN, A. / MAENNIG, W. / ZIMMERMANN, P.: How to Win the Olympic Games - The Empirics of Key Success Factors of Olympic Bids, 2007.

AHLFELDT, G. / MAENNIG, W.: The Role of Architecture on Urban Revitalization: The Case of "Olympic Arenas" in Berlin-Prenzlauer Berg, 2007.

MAENNIG, W. / SCHWARTHOFF, F.: Stadium Architecture and Regional Economic Development: International Experience and the Plans of Durban, October 2006.

FEDDERSEN, A. / VÖPEL, H.: Staatliche Hilfen für Profifußballclubs in finanziellen Notlagen? - Die Kommunen im Konflikt zwischen Imageeffekten und Moral-Hazard-Problemen, September 2006.

FEDDERSEN, A.: Measuring Between-season Competitive Balance with Markov Chains, July 2006. 


\section{Hamburg Contemporary Economic Discussions}

(Download: http://www.uni-hamburg.de/economicpolicy/hced.html)

01/2006 FEDDERSEN, A.: Economic Consequences of the UEFA Champions League for National Championships - The Case of Germany, May 2006.

04/2005 BUETTNER, N. / MAENNIG, W. / MENSSEN, M.: Zur Ableitung einfacher Multiplikatoren für die Planung von Infrastrukturkosten anhand der Aufwendungen für Sportstätten - eine Untersuchung anhand der FußballWM 2006, May 2005.

03/2005 SIEVERS, T.: A Vector-based Approach to Modeling Knowledge in Economics, February 2005.

02/2005 SIEVERS, T.: Information-driven Clustering - An Alternative to the Knowledge Spillover Story, February 2005.

01/2005 FEDDERSEN, A. / MAENNIG, W.: Trends in Competitive Balance: Is there Evidence for Growing Imbalance in Professional Sport Leagues? January 2005. 


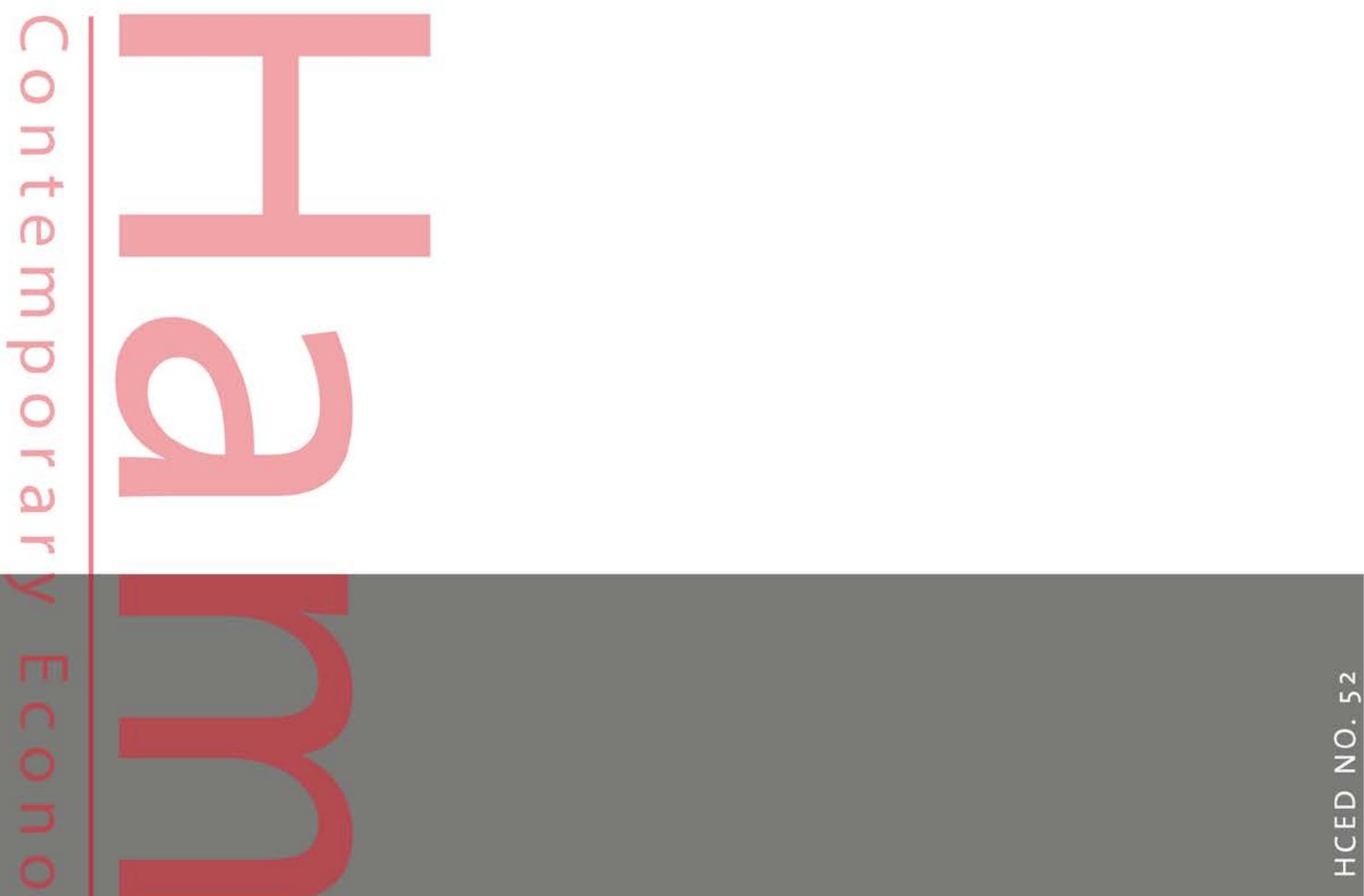

ISSN 1865-2441 (PRINT)

ISSN 1865-7133 (ONLINE)

ISBN 978-3-942820-18-9 (PRINT) ISBN $978-3-942820-19-6$ (ONLINE) 